\title{
To What Extent Does Split Intransitivity of the Adult Target Affect Children's Emerging Verb Patterns?
}

\begin{abstract}
By John M. Ryan*
The Unaccusative Hypothesis has produced several diagnoses for determining whether a given intransitive verb is unaccusative or unergative. While some are suggested to be language-specific, like ne in Italian or pleonastic "there" in English, others have a wider application, such as the distribution of BE and/or HAVE as the perfect auxiliary. The distinction, or not, of HAVE/BE auxiliaries in adult input would arguably have major implications for children acquiring their first language, particularly in terms of the acquisition of the notion of split intransitivity. Languages like Italian, Dutch, or French which make the auxiliary distinction would seem to provide greater transparency to children in terms of split intransitivity while others like English or Spanish would be less transparent because they utilize only HAVE, although earlier versions of these languages are attested to have also possessed at one time both auxiliaries. This study draws on four CHILDES data sets to compare the early emergence patterns of intransitive verbs in four monolingual children (two from each language) learning Spanish and Italian. Cross-linguistic observations of the data include: 1) an initial predominance of unaccusative verbs at the oneand two-word stages; and 2) particular morphology corresponding to early verb types, namely, initial preference for third-person, singular, past tense verb forms with unaccusatives and the singular imperative with unergatives. The study concludes that, despite an apparent lack of transparency in adult Spanish language input, monolingual children learning Spanish may demonstrate a comparable degree of early sensitivity to split intransitivity as their monolingual counterparts who are exposed to adult Italian, attributing the similarity to inherent structural differences between unaccusatives and unergatives and Universal Grammar.
\end{abstract}

\footnotetext{
*Assistant Professor of Spanish Linguistics, University of Northern Colorado, USA

The results and findings in this paper were made possible by a Spring 2013 University of Northern Colorado Faculty Reassignment Award.
} 


\section{Introduction and Purpose}

Since the Unaccusative Hypothesis (Perlmutter, 1978), split intransitivity has been observed to manifest itself in a number of ways both within and across languages. Such behavior has become a rule-of-thumb diagnosis for determining whether a given intransitive verb is unaccusative or unergative. Although some diagnoses appear to be language-specific, such as distribution of the clitic ne in Italian or the ability to insert the pleonastic pronoun there in English, some may have a much wider, though not exclusive, cross-linguistic application, such as the ability to derive an agentive noun by adding such affixes as -ER or -IST, or the distribution of BE and/or HAVE as the perfect auxiliary. Because they make the HAVE or BE distinction, languages like Italian, Dutch, or French appear more transparent in terms of split intransitivity while others like English and Spanish are less transparent because they utilize only HAVE, although earlier versions of these languages have been attested to possess both auxiliaries.

Given the seeming difference in transparency of these two types of languages, this study asks the question whether level of transparency of split intransitivity in adult input affects the early emergence patterns of intransitive verbs in monolingual children learning those languages. To do this the longitudinal acquisition data of two languages (from the Child Language Data Exchange System) which lie at opposite ends of the transparency spectrum are compared with regards to split intransitivity. Drawing on first language acquisition data from two reported imperative analog "languages" (Salustri \& Hyams, 2008), namely, Spanish and Italian from CHILDES (MacWhinney, 2000), this new analysis, which builds on prior work for Spanish (Ryan, 2009 $\&$ 2012), in addition to proposing correlations with morphological form of the verb, includes two variables not studied previously, namely: 1) the emergence of argument-specific, intransitive verb types or classes, such as unaccusatives (Theme-type) and unergatives (Agent-type); and 2) how these might correlate with each other and unfold over three time periods: a) one-word, b) two-word, and c) early multi-word stages of language production.

\section{Background}

Split intransitivity is the notion that intransitive verbs, or verbs with a single argument, come in two varieties: 1) unaccusative; and 2) unergative. Unaccusatives are those verbs whose single argument is theme-oriented and can appear in canonical fashion as in (1), or in the form of pseudounaccusatives as in (2):

(1) Her flight arrives at one

(2) The doll broke. 
In the first case, the verb only appears in the intransitive sense. In the second case, however, the verb may also appear alternatively in a transitive construction as in (3). As such the intransitive variant in (2) is often referred to as 'anticausative.'

(3) Mary broke her doll.

Unergatives, or the second type of intransitive, is one whose single argument is agent-oriented and like unaccusatives can also appear in both canonical and non-canonical fashion. Canonical unergatives verbs such as 'sneeze' in (4) only appear intransitively whereas non-canonical unergatives such as 'write' in (5) may also appear transitively as in (6):

(4) Jane sneezed.

(5) We write often.

(6) Sam is writing a book about locomotives.

Cross-linguistic analysis suggests that some languages exhibit unique characteristics in terms of split intransitivity. For example, in Italian it has been pointed out (Burzio, 1986) that the clitic particle ne only appears in constructions involving themes, including both transitive and unaccusative constructions as in (7), whereas it cannot appear in constructions that lack a theme argument such as unergatives, as in (8).

(7) Ne arriveranno molti.

'Many will arrive.'

(8) *Ne telefoneranno molti.

'Many will telephone.'

English too offers particular behavior with regard to split intransitivity in terms of its application of the pleonastic pronoun 'there' whereby unaccusatives are more likely to admit the pleonastic than unergatives as in (9) and (10).

(9) There remains little hope.

(10)*There sings the diva.

There are other characteristics of split intransitivity that apply more generally though not exclusively across languages. These include the ability to derive agentive nouns by adding-ER, -IST, or -ANT (e.g., 'singer,' 'typist,' or 'informant') versus more thematic (used here as pertaining to a Theme argument) ones with -ED, -EN or -EE (e.g., 'newly arrived,' 'fallen,' or 'escapee'). Another more common indicator of split intransitivity is the distribution of HAVE and/or BE as the perfect auxiliary as in (11) and (12) in Modern Italian,

(11) $\mathrm{Ho}$

have-PRS.PRF.AUX.1SG pianto. cry-PST.PTCP 'I cried.' 
(12) Sono be-PRS.PRF.AUX.1SG

arrivato. arrive-PST.PTCP 'I arrived.'

It would seem that languages having an alternating HAVE/BE perfect auxiliary system would make split intransitivity more salient than languages which only exhibit HAVE. This leads us to ask whether children learning languages like Modern Spanish or English would exhibit as much or even any sensitivity to the split as Italian, Dutch or French children who are constantly exposed to the split in their input.

\section{Methodology}

The research question posed here is the following: Does a child exposed to the adult input of a language which is rich in indicators of split intransitivity, as is adult Modern Italian, show more sensitivity to this notion than does a child exposed to the adult input of a language which is devoid of the same indicators, as is adult Modern Spanish? The data sets studied were selected from CHILDES (Child Language Data Exchange System) (MacWhinney, 2000), namely, for Spanish: 1) "Irene" (Llinàs-Grau, 2000); and 2) "Emilio" (Vila, 1990) databases, represented in this study as SP(1) and SP(2), respectively; and for Italian: 1) "Francesco" (Volterra, 1976); and 2) "Marco" (Tonelli, 2005) databases, represented by IT(1) and IT(2), respectively. The inventory of verbargument configurations include two single argument (intransitive) configurations, namely: 1) Theme-only configurations such as anticausative structures of ergative predicates (e.g., caer 'fall', abrir 'open') as well as unaccusatives (e.g., ir 'go', venir 'come'); and 2) Agent-only configurations such as unergatives as dormir 'sleep'. Two- or more argument (transitive or ditransitive) configurations never appeared in the early data so they are not studied here.

\section{Results}

Italian and Spanish Data Compared in Terms of Emerging Verb Type

Table 1 compares the sequence of verb types as they emerged for the first time in the data for the four children (two Spanish and two Italian) of this study. Verbs are shown in the infinitive so that a focus can be made on intransitive verb type as either unaccusative or unergative, and not morphological form, the latter which is reserved for the following section of this paper.

Perhaps the most striking observation of the data in Table 1 is the variability in timing of the appearance of the earliest verbs in the children studied. Two of the children start producing verbs well before the age of 1;2.00, while another not until 1;6.02. For one of these children IT(1), no data is available before 1;4.03 (indicated by the blackened area in Table 1), 
however, given the number and variety of verbs appearing at this stage, it is quite possible that verbs appeared before this time period as well.

Despite this variability in timing, striking similarities are observed in terms of the types of intransitive verbs which are observed to first appear. Three of the four children, both the Italian children IT(1) and IT(2), and one Spanish child (SP(1), demonstrate remarkable similarity in their trajectories. For all three children, their first verbs are either predominantly, if not exclusively, unaccusative (indicated by grey shading in Table 1 to facilitate illustration). A closer look at unaccusative type, in two of the three children who produced this as a first type, IT(1) and IT(2), reveals that there is no initial preference for either the canonical (e.g., 'go' or 'sit') or pseudo-unaccusative, i.e., anticausative (e.g., 'break', 'close', or 'finish') variety, both appearing at the same time. Only in one child (SP1) did canonical unaccusatives appear first. Soon after the initial appearance of unaccusatives, all three children following this similar path then began to produce unergatives (indicated by unshaded boxes in Table 1 to contrast the grey ones corresponding to unaccusatives).

Table 1. Comparison of Spanish and Italian Data in terms of Emerging Verb Type

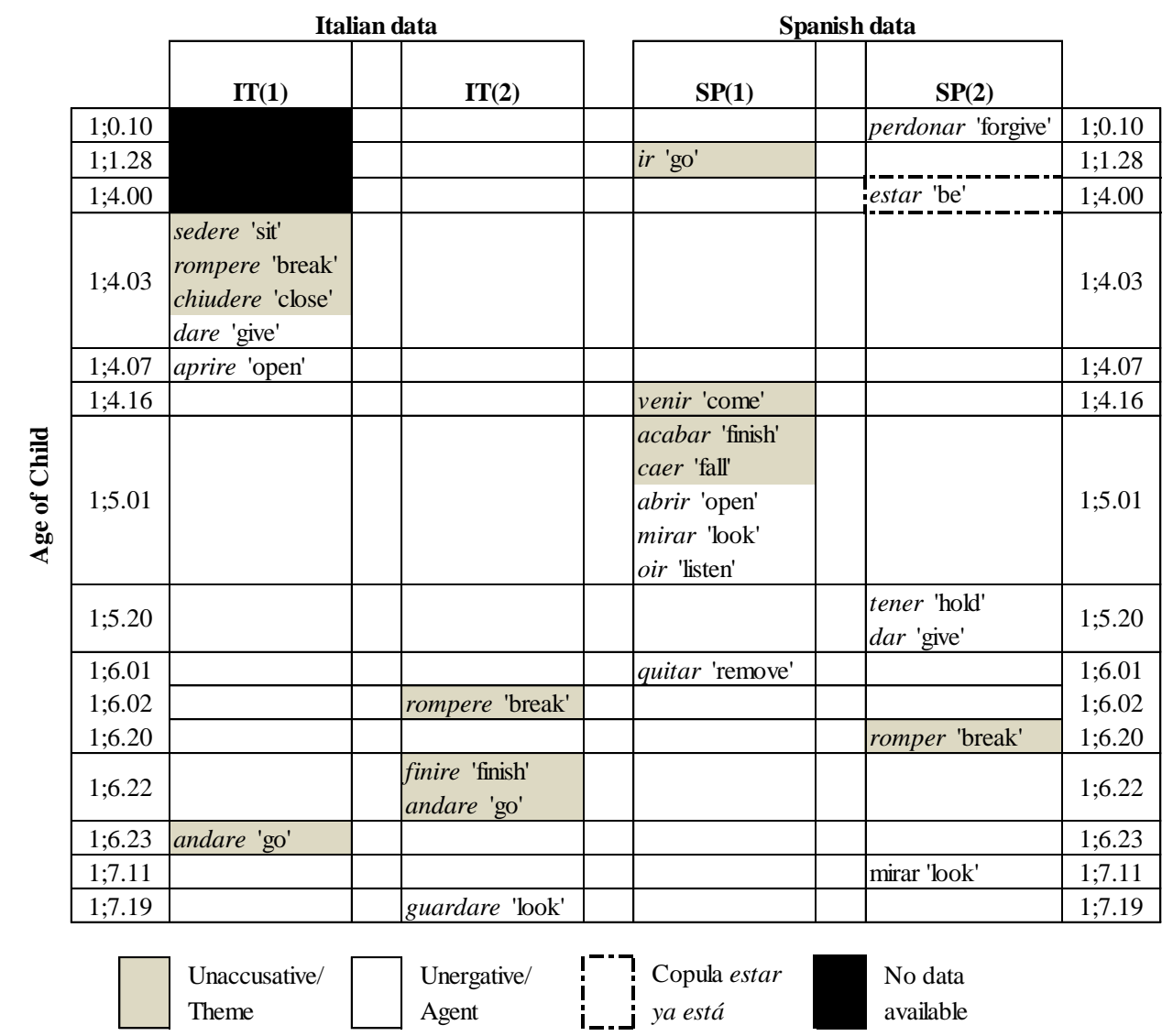

Unlike the other three children of this study, SP(2) at first appears to be an anomaly among the rest because, unlike the others, he appears to first produce 
(at $1 ; 0.10$ ) not the expected unaccusative, but an unergative, namely, perdonar 'to forgive.' In fact, even the subsequent verb he produces (at 1;4.00) is neither unaccusative or unergative, but rather a very specific use of the copular verb estar 'to be', in the expression ya está, roughly meaning 'that's it' to indicate that something is finished. Not until 1;5.20 does $\operatorname{SP}(2)$ produce his two new verbs, again unergative, with tener 'hold' and dar 'give'. Not until 1;6.20 does SP(2) produce his first unaccusative in the anticausative use of romper 'break'. An explanation for why this child might have followed a different trajectory in terms of the order of verb type produced as compared to the other children of this study is reserved for the "Discussion and Conclusions" section of this paper.

\section{Early Morphology of Italian and Spanish Unaccusatives Compared}

As noted in Table 1 of the previous section, unaccusative verbs are the first intransitive verb type to appear in three of the four children of this study. Morphology is an especially important variable to study in child's speech, especially at the one-word stage of language acquisition. This section will analyze the emergence and distribution of the morphology corresponding to all unaccusatives produced by the children of this study. A comprehensive review of the data shows an overwhelming similarity by all four children of the study to use either the past participle or a third-person past tensed form for themeoriented verb types (unaccusatives and anticausatives). More specifically, both Italian children, IT(1) and IT(2), as well as the second Spanish child's SP(2) first form of choice for unaccusatives was unanimously, the bare past participle. Unlike the other children three children, SP(1) never demonstrated an initial phase of past participle usage, but rather started producing all unaccusatives exclusively in the third-person singular preterit (past tense) form.

A closer look at the Italian data reveals that beyond initial use of the bare past participle, the past tense of choice exclusively chosen for unaccusatives is the third-person singular passato prossimo (loosely-translated as the "recent past" tense) which is roughly equivalent (more so in form than in meaning) to the present perfect tense in English. Initially, at 1;4;03, IT(1) produces the bare participial form uto (13) and after only two weeks (at 1;04;27) he starts producing the full passato prossimo form with both auxiliary and past participle for another verb, rompere 'to break,' as seen in (14). The second Italian child IT(2) doesn't produce his first unaccusative verb until 1;06;22, but he too, like IT(1), does so at first with the bare participial form, as seen in (15).

(13) (sed)uto sit.down-PST.PTCP 'seated' IT(1)--1;04.03

(14) èoto be-PRS.PRF.3SG break-PST.PTCP 'It broke' IT(1)--1;04;27

(15) fi(ni)to finish-PST.PTCP

'finished' IT(2)--1;06.22 
A closer look at the Spanish data reveals that, although $\operatorname{SP}(2)$ was observed in the previous section to be an anomaly in terms of the order of verb type acquired, when it comes to verb morphology, this same child appears to follow a similar pattern to both Italian children of the study, in the sense that his first unaccusative verb, once it is finally produced, is a bare participial form, as seen in (16). On the other hand, in terms of morphology, it is SP(1) who appears to be the anomaly as compared to the other three children. From her earliest transcripts, SP(1) starts producing very recognizably third-person singular preterit forms, although some of these appear to be regularized lexical innovations for forms that are irregular in the adult target. For example, (17) shows that at $1 ; 2 ; 05, \mathrm{SP}(1)$ produced the form $v o$, a past tense innovation (as opposed to the irregular adult target se fue) that applies the standard thirdperson singular preterit tense morphology $-o$, to the regular present tense form $v a$. Shortly thereafter, by $1 ; 5 ; 01$, the same child expands her verbal repertoire further to include past-tensed anticausative forms of ergative verbs, as in (18) abó (acabó = target adult form) 'it finished,' or in (19) tayó (target adult form = cayó) 'It fell.'

(16) roto

$$
\text { break-PST.PTCP 'broken' SP(2)--1;06.20 }
$$

(17) vo

$$
\text { go-PST.3SG 'It went SP(1)--1:02;05 }
$$

(18) abó

$$
\text { end-PST.3SG 'It ended SP(1)--1;05;01 }
$$

(19) tayó toro

Fall-PST.3SG bull-OBJ.UNACC 'Bull fell' $\quad$ SP(1)--1;09;10

\section{Early Morphology of Italian and Spanish Unergatives Compared}

Unlike Italian and Spanish unaccusatives, which, as seen in the preceding section, almost exclusively manifested themselves in the data initially in either participial or third-person singular past tense form, unergatives in all four children followed quite a different morphological trajectory from the outset of their production. In the data of all four children studied, at least initially, unergatives never appeared in either participial or tensed form, but rather appeared exclusively in the form of the singular imperative.

In terms of the Italian data, (20), (21), and (22) all show that IT(1) never deviates from use of the imperative form. Likewise, IT(2) follows the very same pattern, as seen in (23) and (24).
(20) dà
(21) $e$
give-IMP
'Give!'
IT(1)--1;04.03
and
apri
(22) (v)edi
look-IMP
open-IMP
'Well, open (up)!'
IT(1)--1;04.27
(23) guarda
'Look!'
IT(1)--1;06.23 
$\begin{array}{lll}\text { (24) } \begin{array}{ll}\text { look-IMP } \\ \operatorname{leg}(g) i\end{array} & \text { 'Look!' } & \text { IT(2)--1;07.19 } \\ \text { read-IMP } & \text { 'Read' } & \text { IT(2)--1;09.01 }\end{array}$

In terms of the Spanish data, SP(1) begins to use such verbs as abe (target adult form $=$ abre) 'Open!' and ;Mia! (target adult form $=$ iMira!) 'Look!' as seen in (25). Eventually, even as imperatives follow an overall downward trend over time, use of the imperative for unergatives is still preferred over both tensed and nonfinite forms for this verb type. Also, when unergatives do finally appear in tensed form they only occur with certain verbs such as volo, 'I fly' or llora '(she) cries' and they certainly never appear in the past or preterit tense as do her unaccusatives. SP(2) also prefers the strict use of the singular imperative for his unergatives, as illustrated in (26).
(25) iMí(r)a!
look-IMP
'Look!'
SP(1)--1;05.01
(26) ;Ten!
have-IMP
'Hold (it)'
SP(2)--1;05.20

\section{Discussion and Conclusions}

One of the goals of this study was to expand upon a preliminary analysis of verb development in one Spanish child (Ryan, 2009 \& 2012) to a larger analysis of the same development in three additional children (a second Spanish child and two Italian children). This was done in order to test the corroborability of the results of the original Spanish data as well as to control for any difference that split intransitivity in adult input might have on the developing language of the children learning these languages. Contrary to what one expects, the data of this study suggests that both Spanish ( $\mathrm{Sp}$ ) and Italian (It) exhibit strikingly similar paths of acquisition by children in terms of split intransitivity, particularly in terms of morphology. As a first stage unaccusatives were found to appear before unergatives in both languages, and in a past tensed verb form, either non-finite (in the past participle) or finite (in the preterit (Sp) or passato prossimo (It)) form.

The initial predominance of theme-type verbs at the one- and two-word stages, included both canonical unaccusatives, such as 'go' ir (Sp)/andare (It) or 'come' venir ( $\mathrm{Sp}$ ) and non-canonical unaccusatives, or anticausatives, such as 'fall' caer (Sp)/cadere (It) or 'break' rompere (It). It was only later, as a second stage when unergative verbs were found to emerge in the data, such as 'look' mirar (Sp)/vedere (It) or 'open' aprire (It). Also, unlike unaccusatives which were tensed, unergatives were found to appear exclusively at first in the singular imperative form. In other words, for both languages studied, despite the input, agentivity appears to come as a later stage and is marked morphologically, even before the child is able to manipulate the perfect tenses. 
In terms of the specific morphology of the forms produced by the children of this study, again, all four children chose a past tense verb form (in Spanish, the past participle or preterit, and in Italian, the past participle or the passato prossimo) for unaccusative verbs (e.g., (Sp) tayó (cayó) 'it fell'; (It) eoto (è rotto) 'it broke'). All children of the study were found to exclusively use the singular imperative with unergative verbs (e.g., (Sp) ;Mira! 'Look!'; (It) Apri! 'Open!').

One possible explanation for this early distinction in behavior between unaccusatives and unergatives results from the inherent structural differences between these two types of verbs in X-bar structure (Chomsky, 1995). Although both children are exposed to different input, basic binary structural relations (X-Bar) within UG hold as both children begin to "build" their trees, hence, both children capitalize at first on the head-complement relation, making unaccusatives easier to produce in both languages, initially without a complement $\left(\mathrm{X}^{0}\right.$ or $\left.\mathrm{X}^{\prime}\right)$. As this head-complement relation is reinforced, unaccusatives can now appear with complements, primarily in post-verbal position ( $\left.X^{\prime}\right)$. Unergatives begin to appear only in the imperative before any overt agent is expressed, suggesting the $\mathrm{CP}$ may be present before the specifier appears within VP (X').

If the conclusions of this study are correct, despite a comparable lack of transparency in adult language input, monolingual children learning Spanish may demonstrate an equal sensitivity to split intransitivity as do those learning Italian, as evidenced by the correlations between verbal morphology and intransitive verb type. As noted, similar correlations were also found to obtain in the Italian data, confirming the split intransitive distinction to lie within the domain of Universal Grammar, with language specific characteristics to be sorted out with later development and with additional input from the target language.

An Explanation for Why the Second Spanish Child of this Study SP(2) May Seem to Have Followed a Different Trajectory

As illustrated in the previous section, the second Spanish child $\operatorname{SP}(2)$ differed from the other three children of this study in that he did not exhibit, like the others, earlier production of unaccusatives before unergatives. To quite the contrary, his first verb to appear was perdonar 'to forgive,' an unergative; this was followed by a moderate period of exclusive use of the expression ya está or 'that's it,' after which unergatives started to appear. It is curious that $\mathrm{SP}(2)$ 's usage of perdonar is restricted to a single occasion and never used again throughout his transcripts. When SP(2)'s initial usage is compared to the first verbs produced by the other children of the study, we find that the other children's first forms, all of which were unaccusative, were highly productive and recurred throughout a sustained period of time, whereas SP(2)'s first verb was a one-time occurrence.

One explanation for this anomaly might be that $\mathrm{SP}(2)$ in this one instance may have been merely repeating a recurring form that was often used by his caregivers. If this is the case, his next period of over-usage of the copular 
expression ya está might in fact be more indicative of his actual initial verb usage and supports the hypothesis of this study in that $\operatorname{SP}(2)$, although he does not at first use unaccusatives, he does not use unergatives either. It is important to reiterate here as well, that despite the fact $\mathrm{SP}(2)$ does not produce unaccusatives earlier, expected correlations of morphology as found for the other children of this study do apply in his case as well.

\section{Emergence of Theme-type Verbs before Agent-type Verbs}

The hypothesis that theme-type verbs emerge before agent-type verbs, finds empirical support in previous work on early verb production, namely, case studies by Volterra (1976) for Italian and Tomasello (1992) for English. Focusing on two children's emergent usage of the past participle in Italian, Volterra (1976) concluded that both children of her study produced type A participles, i.e., expressive of a state (e.g., Luisa è uscita 'Luisa has gone out') almost a year before they could produced type B participles, i.e., expressive of accomplishments (e.g., Luisa ha dormito 'Luisa has slept'). This familiar dichotomy for intransitive verbs that Volterra refers to is of course what would later be referred to as the Unaccusative Hypothesis (Perlmutter, 1978) with subsequent observations for Italian (Burzio, 1986).

Similar observations in terms of timing of the emergence of verb types were made by Tomasello (1992) who observed the inventory of verb use by his daughter in terms of cognitive structure and social-pragmatic learning contexts. Tomasello found that around the age of 1;3 the earliest appearing "verbs" were those that were related to movement or change (e.g., 'stuck' and 'gone') long before those of intentional action. Because his focus had more to do with underlying cognitive structure, Tomasello doesn't express these verb types in terms of unaccusativity, unergativity, or transitivity, but suffice it to say that the early verbs he cites as those of movement or change are unaccusative while those of activity are typically agentive.

As to an explanation for why the child would produce theme verbs before agent verbs this study draws upon the pioneering work by Piaget (1970) in the area of cognitive development. Piaget suggested that the earlier sensory motor stage of psychological development, estimated between 12 and 24 months of age, is a period when a child interprets the outside world as nothing more than an extension of herself. According to Piaget, at this stage a child is unable to consider anyone else's needs, wants or interests, and is therefore considered 'ego centric'. It is also during this stage when the child acquires knowledge about objects and the ways that they can be manipulated. Through the acquisition of information about self and the world, and the people in it, an infant begins to understand how one thing can cause or affect another, and begins to develop simple ideas about time and space. Unaccusatives by their very nature have everything to do with movement and a complete lack of intentional action or agentivity. This would explain why both Spanish and Italian children of this study were observed to utilize past tensed anticausative variants of the ergative verbs 'break,' 'end,' and 'close' before their transitive counterparts. 


\section{Comments on the Past Participle and Imperative Forms Found in this Study}

The author suggests that the use of the past participle found in the Italian children at the earlier stages of the data may in fact be truncated versions of the full, third-person singular passato prossimo form. In Italian, the third-person singular present tense form of the copula essere 'to be' is a phonologically insubstantial form (i.e., $\grave{e}$ ) and so it would not be surprising that this portion of the tense combination be suppressed, particularly at the one-word stage of acquisition. As the data also shows, when the auxiliary does finally begin to appear it is always this third person singular form of essere, or $\grave{e}$.

Additionally, the idea that the imperative could serve as an early substitute for agentive constructions in children, much like infinitives do in children learning root infinitive languages, appears to align with the suggestion by researchers that the imperative structure itself may operate in adults as an impoverished structure, a defective clause without a TP in the sense that the imperative tends to operate without tense and person differentiation (Zanuttini, 1991; Rupp, 1999), again, much like infinitives.

\section{Next Steps and Future Research}

The expansive nature of this study is just the first step of a larger study in progress whose goal is to determine the emergence of agentivity in child language and its potential correlation with verb morphology, as a child makes the transition between one-, two-, and early multi-word stages of language production. Similar analyses are planned which will utilize other early longitudinal datasets that include: 1) other so-called imperative analog languages (Salustri \& Hyams, 2008) besides Spanish and Italian, such as Portuguese, Catalan, etc., to see how they compare to the findings of this study; 2) so-called root infinitive languages (Hoekstra \& Hyams, 1998), such as French, Dutch, German, etc., to determine: a) how findings for these languages compare to those found for imperative analog languages in terms of agentivity, and b) any implications this has for the notion of early coexistence of tensed and non-tensed forms; and 3) so-called bare form/small clause languages (Radford, 1991), such as English, to see how findings compare to those found for imperative analog and root infinitive languages.

\section{Bibliography}

Burzio, L. (1986). Italian syntax. A government-binding approach, Dordrecht, Reidel. Chomsky, N. (1995). The minimalist program, Cambridge: MIT Press.

Hoekstra, T. \& N. Hyams. (1998). 'Aspects of root infinitives.' Lingua 106: 81-112.

Hyams, N. (1996). 'The underspecification of functional categories in early grammars.' In: H. Clahsen(ed.), Generative perspectives on language acquisition: Empirical findings, theoretical considerations and crosslinguistic comparisons, Amsterdam/Philadelphia: Benjamins.

Llinàs-Grau, M. (2000). Desarrollo de las categorías gramaticales: Análisis contrastivo de la adquisición lingüística temprana del inglés, castellano y catalán. 
Research Project awarded by the Spanish Ministry of Science and Technology (BFF2000-0504), Universitat Autónoma de Barcelona.

MacWhinney, B. (2000). The CHILDES project: Tools for analyzing talk. $3^{\text {rd }}$ ed. Mahwah, NJ: Lawrence Erlbaum Associates. Available at http://childes.psy. cmu.edu/ [25 January 2007].

Perlmutter, D. (1978). 'Impersonal passives and the Unaccusative Hypothesis.' In: Proceedings of the 4th Annual Meeting of the Berkeley Linguistics Society, UC Berkeley.

Piaget, J. (1970). The child's conception of physical causality. [Translated by M. Gabain]. London: Routledge \& K. Paul.

Radford, A. (1991). Syntactic theory and the acquisition of English syntax: The nature of early child grammars of English. Wiley-Blackwell.

Rizzi, L. (1994). 'Some notes on linguistic theory and language development. The case of root infinitives.' Language Acquisition 5(4): 371-393.

Rupp, L. (1999). 'Aspects of the syntax of English imperatives.' Ph.D. diss., University of Essex,

Ryan, J. (2012). The genesis of argument structure. Observations from a child's early speech production in Spanish. Lambert Academic Publications.

Ryan, J. (2009). 'A child's early overuse of the imperative to express agentivity in Spanish.' In: Proceedings of the Generative Approaches to Language Acquisition in North America (GALANA) Conference, September 2008. Cascadilla Press.

Salustri, M. \& N. Hyams. (2008). 'Looking for the universal core of the RI stage.' In: V. Torrens \& L. Escobar(eds.), The acquisition of syntax in Romance languages. Amsterdam: John Benjamins.

Tomasello, M. (1992). First verbs: A case study of early grammatical development. Cambridge University Press.

Tonelli, L. \& M. Fabris. (2005). 'L'acquisizione della flessione verbale. Esemplificazione di un metodo di ricerca.' AnnalSS 2: 13-34.

Vila, I. (1990). Adquisición y desarrollo del lenguaje. Barcelona: Graó.

Volterra, V. (1976). 'A few remarks on the use of the past participle in child language.' Journal of Italian Linguistics 2: 149-157.

Zanuttini, R. (1991). 'Syntactic properties of sentential negation: A comparative study of Romance languages.' Ph.D. diss., University of Pennsylvania. 